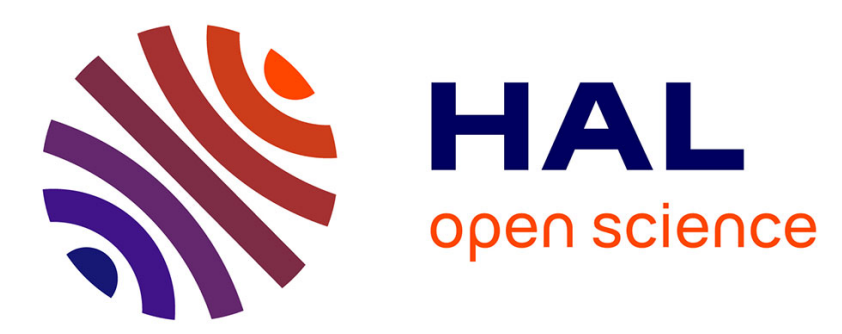

\title{
In vitro cultivation of Cryptosporidium parvum in the non-adherent human monocytic THP-1 cell line
}

Philippe Lawton, Muriel Naciri, Roselyne Mancassola, Anne-Francoise Pétavy

\section{To cite this version:}

Philippe Lawton, Muriel Naciri, Roselyne Mancassola, Anne-Francoise Pétavy. In vitro cultivation of Cryptosporidium parvum in the non-adherent human monocytic THP-1 cell line. Journal of Eukaryotic Microbiology, 1997, 44 (s6), pp.66S. 10.1111/j.1550-7408.1997.tb05783.x . hal-02110909

\section{HAL Id: hal-02110909 \\ https://univ-lyon1.hal.science/hal-02110909}

Submitted on 26 Apr 2019

HAL is a multi-disciplinary open access archive for the deposit and dissemination of scientific research documents, whether they are published or not. The documents may come from teaching and research institutions in France or abroad, or from public or private research centers.
L'archive ouverte pluridisciplinaire HAL, est destinée au dépôt et à la diffusion de documents scientifiques de niveau recherche, publiés ou non, émanant des établissements d'enseignement et de recherche français ou étrangers, des laboratoires publics ou privés. 


\section{In Vitro Cultivation of Cryptosporidium parvum in the Non-Adherent Human Monocytic THP-1 Cell Line}

PHILIPPE LA WTON ${ }^{*}$, MURIEL NACIRI' ${ }^{2}$, ROSELYNE MANCASSOLA ${ }^{2}$, ANNE-FRANCOISE PETAVY1
1 Lab. Parasitologie, Fac. Pharm., Univ. Claude Bernard, Lyon, France, ${ }^{2}$ Station Pathol. Aviaire \& Parasitol., Nouzilly, France

SUMMARY. This study shows that the human monocytic cell line THP-1 supports the growth of $C$. parvum. Immunofluorescence controls showed that only scarce cocysts remained after infection and disappeared within the firtst $24 \mathrm{~h}$ of culture. A continuous asexual life cycle proceeded throughout the experiments, with at least 15-d cultures. This model provides a useful tool for studies on the biology of $C$. parvum in cells involved in its transport in immunocompromised host. KEYWORDS. Cryptosporidium parvum. THP-1 cells. in vitro culture.

Cryptosporidium parvum has been cultivated since 1984 [3] in several cell lines with varying success. Despite its low species and cell specificity, this enteric protozoan is difficult to maintain in the laboratory and an easy to perform and reproducible in vitro model is still lacking. Cultivation in adherent cell lines is often hampered by the overgrowth and peeling of the monolayers, hence, the use of free host cells should provide an enhanced probability for the invading parasites to gain access to a receptive cell. As macrophages and $M$ cells are thought to transport the parasite to other locations in vivo [4], the use of THP-1 cells could give an insight to this capability.

MATERIALS AND METHODS. The non-adherent monocytic THP-1 cells (ECACC 88081201) were grown in RPMI-1640 (DAP) supplemented with $25 \mathrm{mM}$ HEPES (Sigma), 10\% Fetal Calf Serum (DAP) and antibiotics $(200 \mathrm{U} / \mathrm{ml}$ penicillin $/ 200 \mu \mathrm{g} / \mathrm{ml}$ streptomycin, Sigma) at $37 \mathrm{C}$ in a $\mathrm{CO}_{2}$ incubator, until they reached a density of about 0.8 to $1 \times 10^{6} / \mathrm{ml}$. Prior to use, they were centrifuged at $160 \mathrm{~g}$ for $4 \mathrm{~min}$. The parasite strain obtained from an immunocompromised child [1] was passaged through neonatal calves or kids. The stools were filtered through sieves of decreasing pore size, stocked at $4 \mathrm{C}$ in $2.5 \% \mathrm{~K}_{2} \mathrm{Cr}_{2} \mathrm{O}_{7}$ and were used within three months. The oocysts were purified on a discontinuous sucrose gradient made from Sheather solution diluted 1:2 and 1:4 and extensively washed in cold (4 C) saline or tap water. They were aseptized in $1.25 \%$ sodium hypochlorite ( 5 $\min$ at $0 \mathrm{C}$ ) and washed for $7 \mathrm{~min}$ at $1500 \mathrm{~g}$ in cold RPMI-1640. Direct infection [5] of the THP-1 cells was carried out by mixing the cell suspension with the washed oocysts under the appropriate volume of culture medium in 6 - or 24 -well micropiates. The oocysts/cells ratio was usually $1: 2$ to $1: 1$ (about $3-6 \times 10^{6} \mathrm{cells} / \mathrm{ml}$ ). The oocysts were allowed to excyst for $2-6 \mathrm{~h}$ in a candle jar, they were removed by low speed centrifugation and washed in RPMI 1640 (160 $\mathrm{g}, 4 \mathrm{~min})$. Fresh cells could be added at this time and the cultures were put back in the candle jar with at least two daily medium changes for the first three days. The cultures were monitored with thin smears made from centrifuged samples stained with $20 \%$ Giemsa in water $(25 \mathrm{~min})$ followed by $1 \%$ Alcian blue in $100 \%$ ethanol. The percentage of infected cells was microscopically assessed with an oil immersion $x 100$ objective. When needed, controls were performed with a commercial fluorescent monoclonal (Cellabs PTY, Bradsure Biologicals) which stains only the oocyst walls and sexual forms, using propidium iodide as a counterstain to visualize the cells and parasites nuclei.

RESULTS AND DISCUSSION. The remaining oocysts were efficiently removed after infection: immunofluorescence provided evidence that only a few oocysts and shells were visible, whereas growing asexual parasites remained unstained by the monoclonal.

The THP-1 cell line is susceptible to $C$. parvum and all the development stages were found. The number of infected cells decreased and sometimes slightly increased between $d-4$ and $d-7$, but the total number of parasites always increased during this period, since about $30 \%$ of the infected cells beared more than 3 and up to 24 parasites (mean: 8 ). The cultures never lasted less than 15 days, some of them up to 30 days.

During the first hours of culture, only trophozoites were observable, but with the Giemsa-Alcian stain, these undifferentiated parasites usually appeared as "empty". Type I meronts appeared early $(6 \mathrm{~h})$ and disappeared within the first $40 \mathrm{~h}$ but could be found, albeit rarely. during long-term cultivation. Type II meronts were observable at 15 -
$16 \mathrm{~h}$ and could be seen throughout the experiments. Immunofluorescent-positive sexual stages were observed from d-2 onward, mimicking the in vivo prepatent period [2]. Although oocyst-like bodies could be found intracellular from $\mathrm{d}-4$ and in centrifuged culture supematants, sub-culturing has been unsuccessful so far. There is evidence however, that the complete cycle takes place (Fig. 1), but production of invasive new sporozoites is less certain.

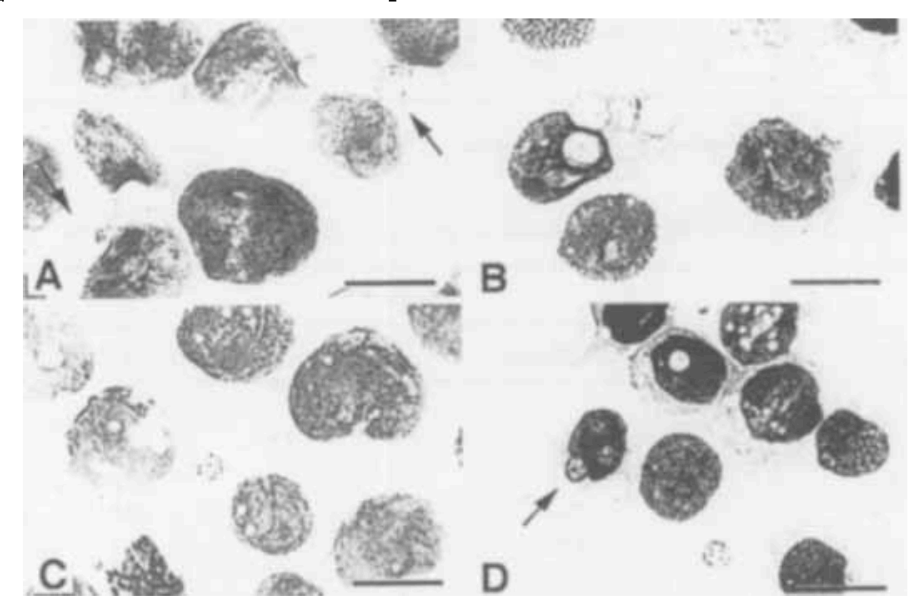

Fig. 1: Microscopy of THP-1 cells infected with C. parvum. A. Undifferentiated stages and late trophozoites (arrows). B. Multiple infections with undifferentiated stages and a developping 8-nuclei type I meront at d-21. C. Macrogamont at $55 \mathrm{~h}$ post-infection. D. Microgamont and maturing oocyst (arrow) at d-4. Bar. $10 \mu \mathrm{m}$.

We describe here a versatile system which provides good infection rates, easy means of controlling and monitoring parasite growth, with the possibility to facilitate time-dependent in vitro tests. The use of non-epithelial and unpolarized cells, a model that differs from the natural intestinal host-cells will provide a useful tool for studies on the biology of $C$. parvum in cells involved in its transport in immunocompromised hosts.

1. Amaud-Battandier F, Naciri M, Fischer A, Ricour C, Griscelli C, Yvoré P. Gastroenterol. Clin. Biol. (1982) 6:1045.

2. Chappell CL, Okhuysen PC, Sterling CR, Dupont HL. J. Infect. Dis. (1996) 173:232.

3. Current WL \& Haynes TB. Science (1984) 224:603.

4. Marcial MA \& Madara JL Gastroenterology (1986) 90:583.

5. Upton SJ, Tilley M, Nesterenko MV, Brillhan DB. FEMS Mictobiol. Lett. (1994) 118:45. 